British \& Irish Botany 3(2): 188-195, 2021

\title{
A new species of Rubus (Rosaceae) from NE Scotland
}

\author{
David Welch \\ Banchory, Kincardineshire, UK
}

\section{Corresponding Author: welcmd@gmail.com}

This pdf constitutes the Version of Record published on $26^{\text {th }}$ July 2021

\begin{abstract}
A distinctive bramble, whose identity has puzzled experts, is described as a new microspecies, Rubus longiflorus D. Welch. It is characterised by large showy white flowers, deeply grooved, glabrous, few-prickled stems, and leaves that have grey-felted undersides. It is considered intermediate between the Discolores series and Corylifolian section of brambles, and is tentatively assigned to the Rhamnifolii series. The new taxon occurs along an $80 \mathrm{~km}$ stretch of coastal lowlands in the Kincardineshire and Angus vice-counties.
\end{abstract}

Keywords: bramble, microspecies, Rubus longiflorus, Kincardineshire, Angus

\section{Introduction}

Soon after the publication of a large handbook describing all then-known British brambles (Edees \& Newton, 1988), came a series of papers adding new species. In one of these (Newton \& Porter, 1994), there was a comment that Sect. Corylifolii was a very neglected grouping within the Rubus genus, quoting from Edees (1975) that for this section "many more taxa needed to be described .... before a comprehensive account can be written". But just four new Corylifolian species were added to the British and Irish list between the 1988 handbook and a bramble atlas published 16 years later (Newton \& Randall, 2004); this increased the section total to 24 species.

In Scotland only one of these newly added Corylifolian species occurred, and there was a similar lack of brambles with Scottish occurrences among the other 27 new Rubus species added to the British and Irish list up to 2004. Candidate brambles for naming are certainly known in Scotland, but the criteria for elevating unnamed types to species that have been generally applied by bramble researchers over recent decades - occurrence in more than one vice-county and in several hectads - are hard to satisfy. There is less lowaltitude ground suitable for brambles in Scotland, and researchers have been quite few and more concerned with general recording in their vice-counties. Now with a break from this work, I describe here a distinctive possible Corylifolian that occurs over an $80 \mathrm{~km}$ range from Dundee to Stonehaven. I call the species Rubus longiflorus, prompted by its racemes being longer and more spectacular than those of other bramble species in the area.

The first definite sightings of a $R$. longiflorus bush were made independently by myself and George Ballantyne (GB) at Catterline in Kincardineshire (v.c.91). The bush lay close to the track descending a steep brae to the shore, and its large flowers doubtless drew our attention. We both had sent sheets to Alan Newton (AN) for determination, and only in 2000 did we realise the connection and confer. My sheets collected in 1996 had been given as "cf rhombifolius" by AN, whereas GB reported about his sending (letter 25 
Sept 2000) that "Alan couldn 't make much of it, suggesting it might be a hybrid between ulmifolius and something else (?/atifolius)". GB added "I wasn 't convinced ... as it looked a perfectly good species to me".

I too was not convinced about "cf rhombifolius" since the specimens differed substantially from a big bush of rhombifolius at Maud in N. Aberdeenshire (v.c.93), which I had taken AN to see when we spent a few days together in July 1996 touring difficult and interesting brambles in NE Scotland. Moreover, I had observed a spectacular $80 \mathrm{~m}$ length of brambles along a road to the coast at Crawton (NO88), $2 \mathrm{~km}$ north of Catterline, which I felt was the same taxon as the Catterline bush. So I sent sheets from Crawton collected in August 2000 to AN in that summer's parcel, together with a silhouette of the 1996 Catterline specimen. This silhouette came back marked "certainly approaches Crawton plants" but the Crawton sheets were surprisingly named hebridensis by AN. In later discussions with GB, we felt AN had considered hebridensis as one parent in a hybrid. But unfortunately a hectad dot for hebridensis in NO88 appeared in the Rubus Atlas (Newton \& Randall, 2004); when this record later appeared in the BSBI Distribution Database (DDb), I rejected it.

In 2001 I decided to enlist other expert opinion, and sent a parcel with both Catterline and Crawton sheets to David Allen (DA). His verdict (letter 18 Sept 2001) was "clearly the same - they defeat me" "nothing like rhombifolius at least as I know that. Perhaps $R$. hebridensis $x$ latifolius, which could account for the ultra-large flowers. A specimen retained for BM". Also in that summer GB returned to bushes in the Dundee area that had puzzled him, but which he thought could be the same as the v.c.91 bushes, and sent sheets to AN receiving a verdict: $R$. anglocandicans. This identity too I doubted, though I agreed with GB that the v.c.90 bushes were the same taxon as the v.c.91 ones. In 2002 I enlisted another expert, Prof. Heinrich Weber in Germany, and sent him Catterline and Crawton specimens. He had a paper on anglocandicans in preparation (Evans \& Weber, 2003) and was definite. In a letter (6 May 2002) he wrote "Unknown to me, probably not named yet and just a local thing". And in a further letter (12 Sept 2003) after I had sent more material he wrote "your plant is much different to anglocandicans even without any significant similarities. The most conspicuous characters of your plant are the rather shallow serration of the leaflets and the shape of the panicle. After all, the matter is "clear cut". Your plant is an unnamed taxon, and should be named only if it is not just a local thing". He added that on the continent this requires a distribution area of about 40-50 km diameter.

I had also sent similar sheets collected on the same day in both vice-counties to DA, but he wrote back (21 Aug 2003) saying that after inspecting the BM`s folder for anglocandicans he felt that the wide variation contained in it, e.g. in whiteness of leaf undersides, didn't preclude the new sheets belonging there. DA considered that the two sheets from the Dundee area, particularly the one from Duntrune Dam, were the most similar to anglocandicans, but he added that with herbarium material the size of flowers was less useful as a separation criterion.

With such different and changing opinions on the identity of these big-flowered brambles, the possibility that they were hybrids, and the small recent advances in dealing with the variability in the Corylifolii and Discolores bramble groups, I decided that I ought to make available a description of the taxon, treating it as a new microspecies. I held back from writing such a paper in the 2000s in the hope of finding more colonies or herbarium specimens from other places. Although two examples of the latter are quite convincing, and have been included in the location table and distribution map in this paper, they have little 
changed the taxon's range. But with my description, batologists across a wider area of Britain may be able to recognise that they too have this taxon.

Rubus longiflorus $\mathrm{D}$. Welch, sp. nov.

Stems mainly arching, though a few procumbent sometimes, usually sharply angled and deeply furrowed, red-purple or brown-purple, often shining, glabrous; prickles 8-12 per 5 $\mathrm{cm}$, on the angles, 4-7 mm long, declining or hooked, red-purple or with yellowish point on bigger ones; leaves digitate or subpedate; leaflets (3-) 5, mid green above, glabrous and occasionally shiny, grey-felted beneath; terminal leaflet obovate-elliptical to sometimes roundish, $c .8 \times 6 \mathrm{~cm}$, coarsely serrate with upper two-thirds sometimes weakly biserrate but lower third usually just very shallowly toothed, acuminate apex $0.5-1 \mathrm{~cm}$, the petiolule about one third as long as lamina; petiolules of basal leaflets $1-3 \mathrm{~mm}$; petiole about as long as basal leaflets, with 8-10 small curved prickles; flowering branch with several ternate leaves below and 1-2 simple leaves above, not leafy to the apex; inflorescence cylindrical and often long, with distant few-flowered axillary branches below; rachis often flexuose, green, brown or reddish-purple, with many hairs above and few, usually small, curved prickles; pedicels with many hairs, some stellate, and a few small weak prickles; flowers 3$4 \mathrm{~cm}$ in diameter; sepals grey-green, densely hairy, short-pointed, mainly reflexed; petals 11-16 x 6-9 mm, white or occasionally slightly pinkish, broadly elliptical; stamens exceed styles, filaments white, anthers glabrous; styles green, young carpels hairy at tips; fruit moderate-sized. Flowering in July and August.

HOLOTYPE: Roadside, Crawton, Kincards., v.c.91, GR NO8742.8031, 14 July 2020. David Welch, D. Welch herb., K56X.

Paratype: Roadside, Crawton, Kincards., v.c.91, GR N0877.803, 22 July 2003. David Welch, BM, 000792157.

\section{Discussion}

Extant colonies are spread $80 \mathrm{~km}$ from Dundee to Crawton, a hamlet south of Stonehaven, and the range would total $110 \mathrm{~km}$ if a specimen from Aberdeen in BM considered the same taxon by David Allen is included (Fig. 1). Judging from the 23 herbarium specimens I assembled from several collections at the 8 extant colonies (Table 1) between 1996 and 2020, and from the descriptions made of fresh material observed during the collections, no differences can be discerned between these colonies. The DUE specimen from Pitscandlie Hill has similar stem grooving and the same quite distinctive leaf shape and colouring; its big ternate leaf with truncate base, short apex and two gibbous lower leaflets, has very close counterparts in Crawton specimens. Photos below show flowering in a typical bush at Duntrune plus an inflorescence at Crawton (Fig. 2) and herbarium specimens from vigorous bushes at Duntrune and Crawton (Fig. 3).

The specimen from Pitscandlie was named Rubus thyrsoideus by the Corstorphines in 1915 probably using the bramble listing in Hooker's $3^{\text {rd }}$ edition (1884, but reprinted 1897). That name had been applied by C. Wimmer in the mid-1800s to brambles in Poland and north Germany which are now placed in the Discolores series. Rogers (1893) in his comprehensive account on British brambles had considered the species "doubtfully British", but reinstated it from a specimen collected in 1895 from v.c.22 (Newton, 1977). In this 1977 paper Newton split off from Discolores a new taxon he named $R$. anglocandicans for brambles with coarsely serrate, white-felted leaves. But from the fuller description in Edees 
\& Newton (1988), $R$. anglocandicans differs from $R$. longiflorus in several key characters, notably flower size (petal size given as $c .10 \times 7 \mathrm{~mm}$ ). The German expert, Heinrich Weber, was quite definite that the v.c.90 and 91 specimens were not anglocandicans, from studying the thyrsoideus-type Discolores he had decided on a new species for forms with larger leaves grey-felted below, which he named $R$. conothyrsoides (Weber, 1977), so was well-qualified to judge.

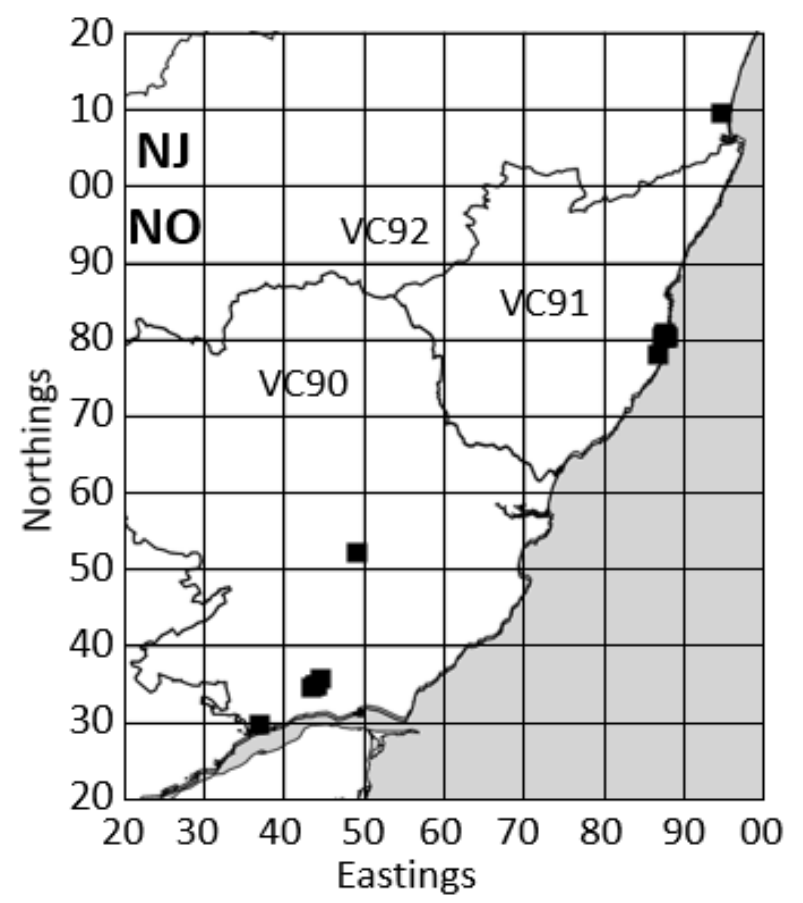

Figure 1. Map showing distribution of current sites of Rubus longiflorus and ones indicated by herbarium specimens collected 1901-1915 ( $($ )

Two more specimens collected by the Corstorphines from Pitscandlie Hill c.1915 are in DUE, one of which they also named $R$. thyrsoideus, but the other $R$. rusticanus. That latter name (synonym $R$. discolor) had been applied by Rogers (1893) to Discolores forms with pink flowers and small leaves white-felted below, and Hooker $(1884 ; 1897)$ made the same distinction from thyrsoideus, this having white flowers and larger leaves, less white below. Alan Newton, visiting DUE in 1977, had written $R$. ulmifolius on the rusticanus sheet, but had baulked at specifying the other two. To me, although one (5249/3) fits $R$. longiflorus well, the other with very serrate leaves is puzzling (5249/2), and possibly could be a relic of a taxon that had been a parent in a hybridisation that had created $R$. longiflorus.

If a hybridisation between a Discolores and a Corylifolian species had produced $R$. longiflorus, then it must have occurred well before the 1910s when the Corstorphines were recording brambles, for the resulting taxon to have spread across its $80-\mathrm{km}$ range. But I do not believe that $R$. longiflorus has this origin rather than being a good long-standing species. I am much more convinced that another specimen (5243/16) collected by the Corstorphines from Melgund $5 \mathrm{~km} \mathrm{NE}$ of Pitscandlie Hill is a hybrid since it has a strange inflorescence with long straggly branches and very few flowers. This was determined as caesius $x$ rusticanus in 1915, and Alan Newton wrote caesius $x$ ulmifolius on the sheet in 1977, but caesius has no records north of the Tay in eastern Scotland. 
On the tricky question of which Rubus group to assign $R$. longiflorus to, it could be either Discolores or Corylifolii for a hybrid between taxa from each, but for a normal species I tentatively suggest Rhamnifolii. This series has species with furrowed glabrous stems, leaves grey-felted, and sometimes large flowers. And it was to that group that Alan Newton originally assigned the Catterline specimen.

Table 1. Occurrence of bushes and colonies of Rubus longiflorus.

\begin{tabular}{|l|l|l|l|l|l|}
\hline Colony & Location & VC & $\begin{array}{l}\text { Extent } \\
\mathbf{2 0 0 3}\end{array}$ & Extent 2020 & Comments \\
\hline \hline $\begin{array}{l}\text { Dundee } \\
\text { Ninewells }\end{array}$ & $\begin{array}{l}\text { NO3684296 } \\
5\end{array}$ & 90 & c.6 sq m & Not Visited & $\begin{array}{l}\text { Foot railway } \\
\text { embankment }\end{array}$ \\
\hline Duntrune S & $\begin{array}{l}\text { NO4341344 } \\
5\end{array}$ & 90 & 1 big bush & $8 \mathrm{~m}$ length & SE verge \\
\hline Duntrune Dam & $\begin{array}{l}\text { NO4402349 } \\
5\end{array}$ & 90 & c.6 sq m & c.4 sq m & Unmanaged ground \\
\hline $\begin{array}{l}\text { Duntrune Dam } \\
\text { field }\end{array}$ & $\begin{array}{l}\text { NO4399349 } \\
5\end{array}$ & 90 & 1 bush & Not Found & $\begin{array}{l}\text { Bush removed } \\
\text { c.2017 }\end{array}$ \\
\hline Duntrune N & NO444357 & 90 & 1 big bush & $30 \mathrm{~m}$ length & W verge \\
\hline *Pitscandlie Hill & NO4953 & 90 & By raspberry field \\
\hline $\begin{array}{l}\text { Catterline coast } \\
\text { brae }\end{array}$ & $\begin{array}{l}\text { NO8684781 } \\
6\end{array}$ & 91 & 1 big bush & 1 bush & First seen 1996 \\
\hline Crawton SE road & NO877803 & 91 & $\begin{array}{l}80 \mathrm{~m} \mathrm{NE} \\
\text { verge }\end{array}$ & $\begin{array}{l}85 \mathrm{~m} \text { on } 2 \\
\text { verges }\end{array}$ & $\begin{array}{l}1 \text { bush now on SW } \\
\text { verge }\end{array}$ \\
\hline Crawton SE road & $\begin{array}{l}\text { NO8777802 } \\
6\end{array}$ & 91 & $\begin{array}{l}1 \text { new bush } \\
4 \mathrm{~m} \text { long }\end{array}$ & SW verge \\
\hline Crawton SW road & $\begin{array}{l}\text { NO8758804 } \\
9\end{array}$ & 91 & $\begin{array}{l}10 \mathrm{~m} \mathrm{NW} \\
\text { verge }\end{array}$ & Gone & Was at field entrance \\
\hline Crawton SW road & $\begin{array}{l}\text { NO8742803 } \\
1\end{array}$ & 91 & & $\begin{array}{l}1 \text { new bush } \\
3 \mathrm{~m} \text { long }\end{array}$ & NW verge \\
\hline $\begin{array}{l}\text { Crawton NW } \\
\text { road }\end{array}$ & $\begin{array}{l}\text { NO8751807 } \\
8\end{array}$ & 91 & 1 bush & Gone & SW verge \\
\hline $\begin{array}{l}\text { Crawton NW } \\
\text { road }\end{array}$ & $\begin{array}{l}\text { NO8744808 } \\
7\end{array}$ & 91 & $\begin{array}{l}1 \text { new bush } \\
4 \mathrm{~m} \text { long }\end{array}$ & SW verge \\
\hline ^Bridge of Don & NJ9409 & 92 & $\begin{array}{l}\text { No suitable habitat } \\
\text { now }\end{array}$ \\
\hline
\end{tabular}

* DUE herbarium, 5249/3, collected 1915, R.H. \& Mrs M. Corstorphine.

AM herbarium, collected 18 Sept 1901, J.W.H. Trail, named ?/atifolius, believed similar to unnamed new taxon by David Allen (letter 28 Aug 2003).

The habitats in v.c.90 and 91 of $R$. longiflorus are mainly roadsides (Table 1 ), but include a steep slope above the shore at Catterline. And at Duntrune Dam a vigorous bush had established in a small under-used field. The soils of these colonies do not seem unusual, so do not explain the present very restricted distribution of the new taxon. For v.c.91, I believe there is little chance of finding new colonies since the coast and even very minor roads near-by have been closely hunted for bramble species. But v.c. 90 has a 
considerable extent of low-ground potential habitat that has not been searched for Corylifolian or Discolores species, rather than Rubus fruticosus agg. Perhaps this paper will result in more colonies of $R$. longiflorus or potential parents, if it were a recent hybrid, being discovered.
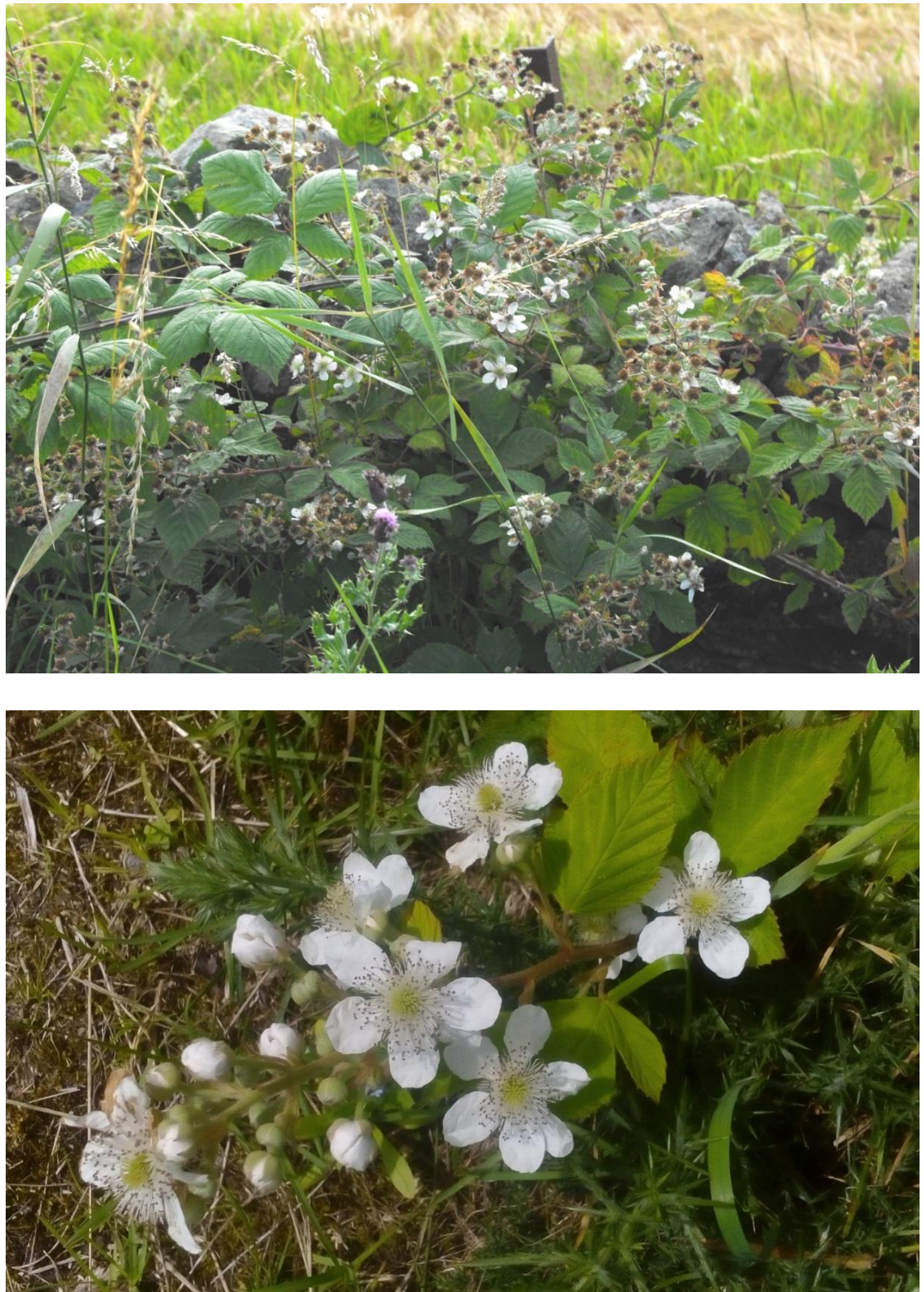

Figure 2. Flowering in Rubus longiflorus. Top: bush at Duntrune $\mathbf{N}$, viewed 13 August 2013; Bottom: inflorescence at Crawton SW, viewed 14 July 2020. 


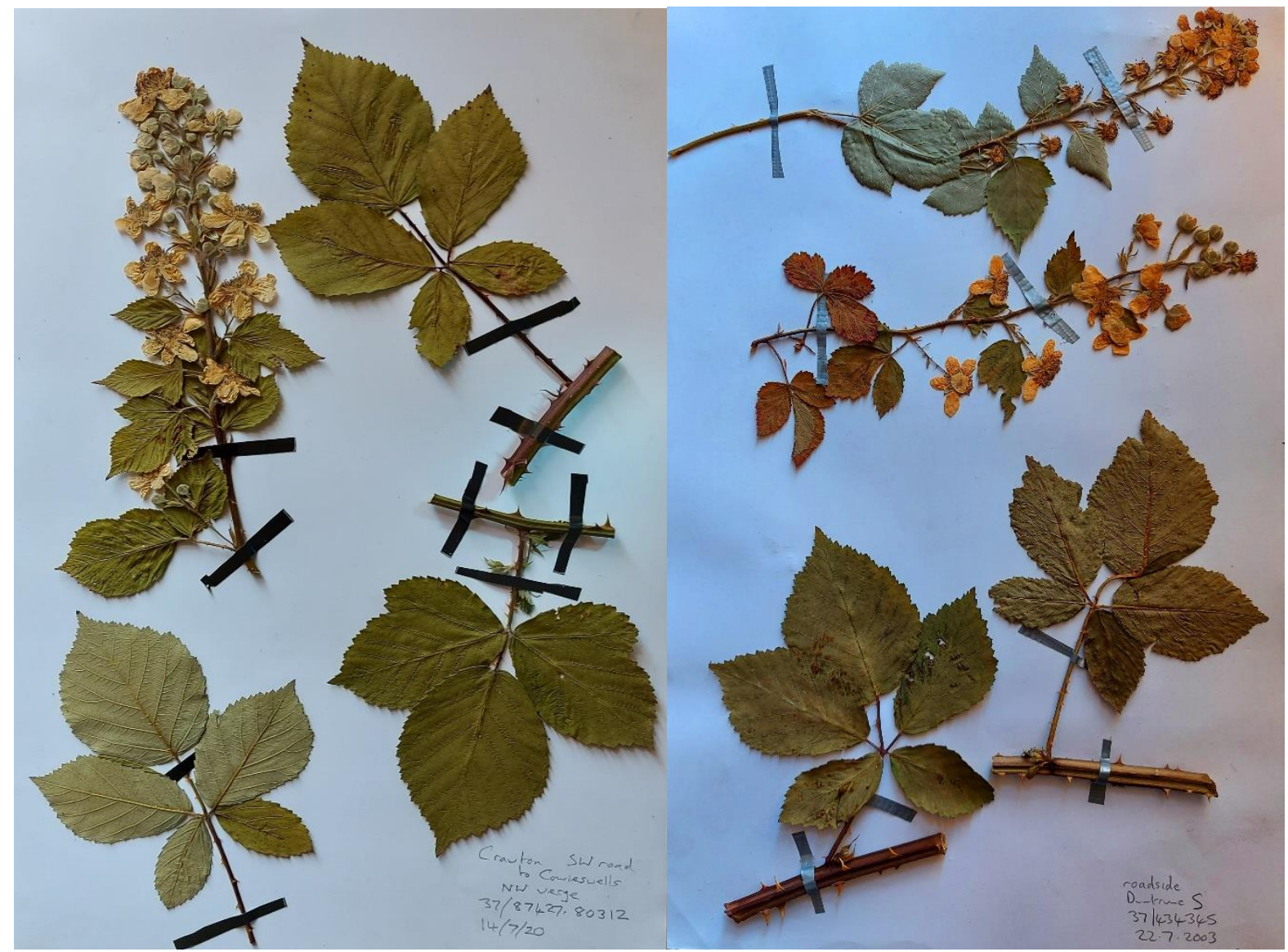

Figure 3. Herbarium sheets from Crawton SW (left, gathered 14 July 2020) and Duntrune S (right, gathered 22 July 2003). Ageing of the latter has caused the green to darken, this having most affected the single lower leaflet of the right-hand upsidedown leaf.

\section{Acknowledgements}

I am grateful to the several bramble researchers named above for their considered opinions on my specimens. Prof. Hugh Ingram, Dundee University, looked at the interesting sheets in the herbarium next door to his office on my several visits. I thank David Elston for producing the distribution map, and Angus Hannah for commenting on a draft.

\section{References}

Edees, E.S. 1975. Notes on British Rubi, 3. Watsonia 10: 331-343.

Edees, E.S. \& Newton, A. 1988. Brambles of the British Isles. London: The Ray Society. Evans, K. \& Weber, H.E. 2003. Rubus anglocandicans is the most widespread taxon of European bramble in Australia. Australian Systematic Botany 16(4): 527-537. Hooker, J.D. 1884. The Student's Flora of the British Isles. London: Macmillan \& Co.. Newton, A. 1977. A review of Rubus section Discolores P.J. Mueller in Britain. Watsonia 11: 237-246.

Newton, A. \& Porter, M. 1994. New species of Rubus L. (Rosaceae) from Wales and the Welsh Marches. Watsonia 20: 133-143.

Newton, A. \& Randall, R.D. 2004. Atlas of British and Irish Brambles. London: Botanical Society of the British Isles. 
Rogers, W.M. 1893. A Key to British Rubi. London (reprinted from Journal of Botany 18921893).

Weber, H.E. 1977. Rubus amisiensis und Rubus conothyrsoides zwei neue Rubus-Arten aus Nordwestdeutschland. Osnabrücker naturwiss. Mitt. 5: 117-129.

Copyright retained by author(s). Published by BSBI under the terms of the Creative Commons Attribution 4.0 International Public License.

ISSN: $2632-4970$

https://doi.org/10.33928/bib.2021.03.188 